\title{
Benefits of Cow Dung - A Human Ignored Gift
}

\author{
M. K. Mohan Maruga Raja ${ }^{1}$, Ravi Manne ${ }^{2}$ and Agilandeswari Devarajan ${ }^{3 *}$ \\ 'Department of Pharmacognosy and Phytochemistry, Parul Institute of Pharmacy and Research, Parul \\ University, Waghodia - 391110, Gujarat, India \\ Environmental and Industrial Hygiene Services, Chemtex, Port Arthur, Texas, United States of America \\ ${ }^{3}$ Research and Development, Synapses AI India Private Limited, Indore, Madhya Pradesh, India; \\ agilandeswaridevarajan@gmail.com
}

\begin{abstract}
Cow is considered as mother and even as god. It is one of the largest domesticated mammals. The meaning of the word panchagavya in Sanskrit is "five cow-derivatives" consisting of three direct constituents like cow urine, dung, milk and the two derived products are curd and ghee. Cow dung and urine are the excretory products. Cow dung is an undigested residue of consumed food material of cow combined with faeces and urine, lignin, cellulose and hemicelluloses being the major composition. Cow dung is an indigestible plant material from the intestine of cow released on to the ground. Generally, faeces, either from an animal or human is not a desired topic of conversation. Cow dung is worth discussing. It's a useful material and helps us in a variety of ways. Cow urine has been used as an antimicrobial not only for rituals but also therapeutically. But cow dung has been mostly used as a firework and/or biofertilizer in the form of cow patties. Researchers have ignored the therapeutical benefits of cow dung which is evident from the smaller number of pharmaceutical products in market amidst of its miraculous benefits. This review discusses about the existing traditional therapeutics and the respective medicinal property of cow dung and tries to change the mindset of the scientific community to carry out the further research in the future.
\end{abstract}

Keywords: Human, Microbe, Medicine, Patties, Protection, Universe

\section{Benefits of Cow Dung - A Human Ignored Gift}

The livestock wealth is considered to be one of the oldest wealth resources for human mankind. This livestock plays a significant role in rural economy and livelihood of people. The 19th livestock censuses 2012 reported that there are around 300 million bovines in India, which is the $18 \%$ of the bovine population existing in the world. The Hindu Vedas mention cow as a holy animal and must be worshiped. Cows are very essential animal resources in India. Cows are vast useful in dairy industry and agriculture ${ }^{1}$. Indiahas 190.9 and 108.7 million cows and buffaloes respectively ${ }^{2}$ (Figure 1 and Table 1). There are around 39 million crossbreds and exotics, which are approximately $20 \%$ of the total cow's population and the remaining $80 \%$ of the population, are indigenous breeds. India has a wide variety of around 43 indigenous breeds of cow (Figure 2). The breeds of Indian cow are distinctive, unique and significant in its external features and characteristics. For over past decades, these breeds have survived with respect to the purpose according to the living surrounding for their products and/or assistance in various activities ${ }^{3,4}$.

\section{The Cow Protection Bill, 2017}

In order to prevent the animal slaughter, it was necessary to form rules and regulations. Hence, a bill was created to form an authority to safeguard the cow population (Bos indicus); to advocate and recommend the measures to suggest such measures to comply with articles 37 and 48 of the Indian constitution. These articles are specific about the ban of cow slaughter. In case, if found to do so, the provisions for a severe punishment which includes both fine, imprisonment and/or both for the issues concerned therewith or incidental thereto ${ }^{5}$.

\section{*Author for correspondence}




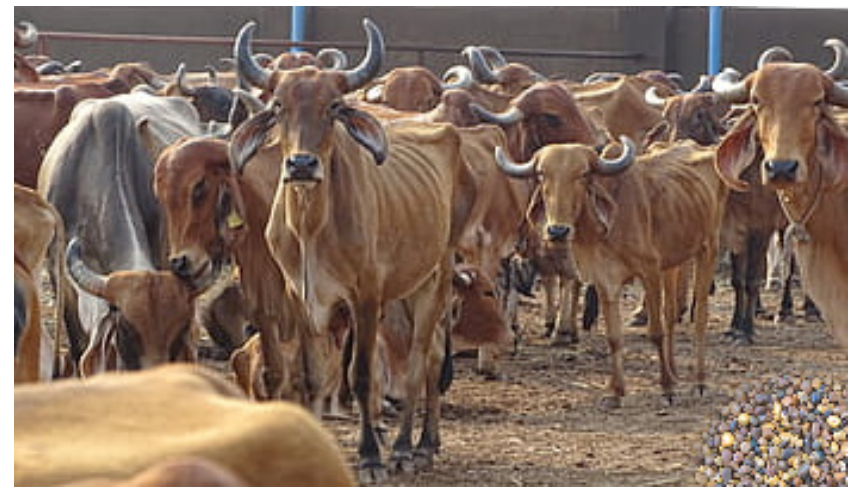

Table 1. Treatment carried out for the patient

\begin{tabular}{|c|c|}
\hline Kingdom & Animalia \\
\hline Phylum & Chordata \\
\hline Class & Mammalia \\
\hline Order & Artiodactyla \\
\hline Family & Bovidae \\
\hline Subfamily & Bovinae \\
\hline Genus & Bos \\
\hline
\end{tabular}

Figure 1. Indian country cow.
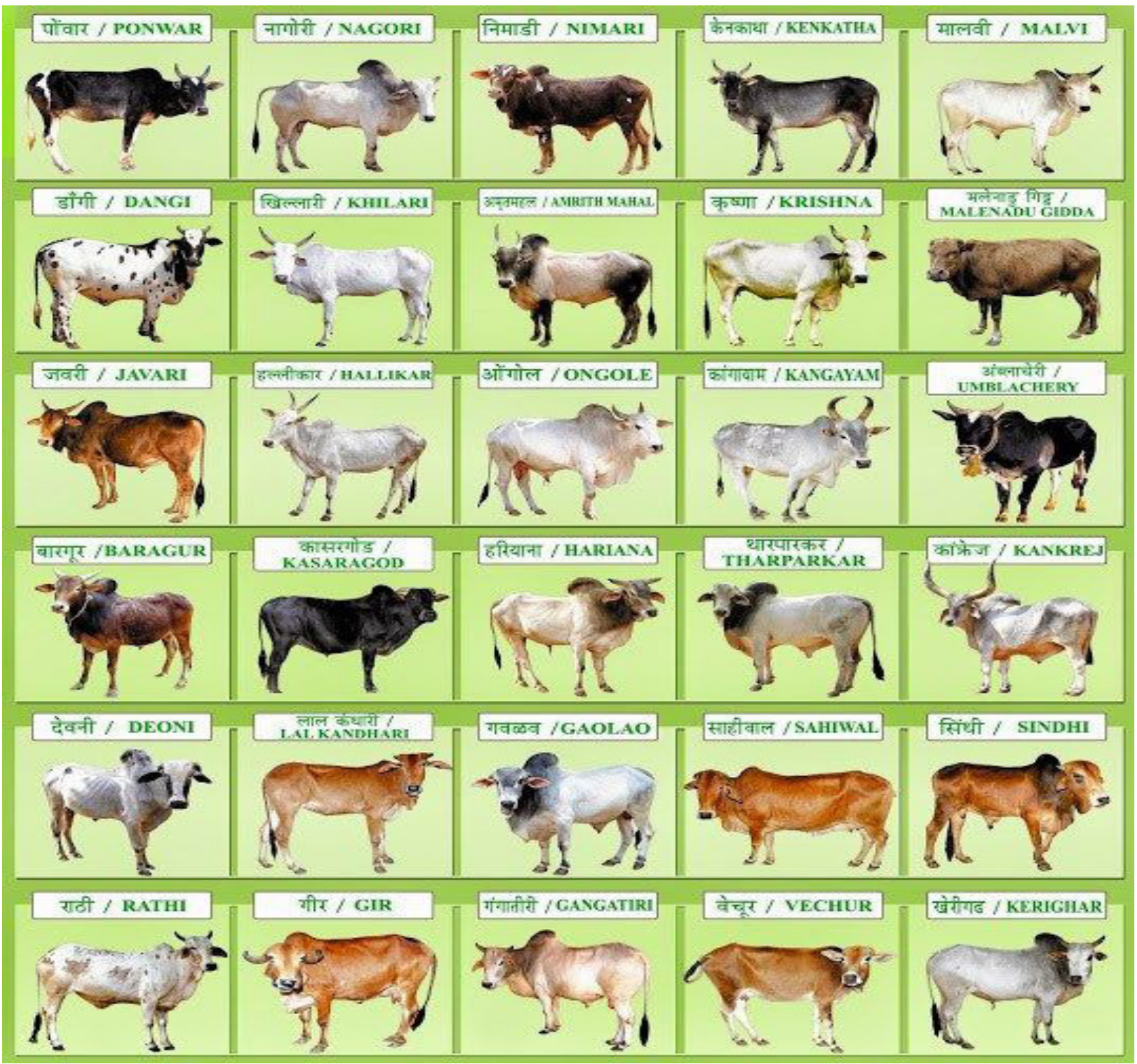

Figure 2. Different cattle breeds of India (Source: http://www.nbagr.res.in/cattle.html). 


\section{Theory Behind "The Sacred Cows"}

The Hindu religion does not avail cow as the source of meat. They use for other purposes like milk, dung for fuel and/or fertilizer, agricultural activities like ploughing and transportation. A study states that majority of foods which cows eat are the wastes like vegetable peels, waste food, rice boil strains which humans throw as the wastes including husks and straw from rice, oil cake after extraction of oil from seeds, etc. The cattle consume the wastes of human use and transforms the same to gives us various products for human use. The underprivileged farmers who are unable to provide food leave them as stray cattle so that it consumes food from the outskirts and reaches home at the dawn leaving the farmer not to spend for them but they provide various products for human use.

Cows are considered as the mothers of the universe. Human mother's feed breast milk to the infant compulsory up to three years and some mothers continue further for few more years. After that, human infant is fed with cow's milk and continues throughout the various stages of human life like childhood, adult and old age. Sometime if a mother is unable to feed her baby due to any diseases or deficiencies, cow's milk is fed without any hesitation. Hence cow's act as a surrogate mother and thereon mother of the world. This makes our human community full of abhorrence and being ungrateful with respect to killing the mother (whether real mother and/or surrogate mother and/or otherwise.). From time immemorial, cows have been a part of civilized life ${ }^{6,7}$ especially in India.

Historical evidences states that the divine "Kamdhenu" was served by Maharishi Vasishta. Panchagavya, a wonderful medicine (a formulation consisting of all the five products of cow such as urine, dung, milk, curd and ghee) was presented by Maharishi Dhanvantari. Also, the Vedic period of Indian civilization describes cow as Kamdhenu, meaning "which fulfils the wishes asked". Cow is trusted as a "mobile hospital" to treat various diseases and deficiencies ${ }^{8}$. In Sanskrit, an individual product is called as "gavya" and the combination of five ("panch"means five) is named as "panchagavya"-11. Panchagavya has been mentioned in the holy scripts of Vedas.

\section{Digestive System in Cow}

The digestion starts with the oral cavity. There are twentyfour molar teeth present which comprises six molars and six premolars each on the upper and the lower jaws sharing twelve each. A wide gap is observed between the incisors and molars teeth. Such an arrangement helps cow to collect, harvest and masticate the large quantities of the fibres present in the feed. Their teeth are principally used for grinding purpose, their tongues are used to cluth or grabble the grass and after which the grindedare pinchedoff between the dental pad and incisors. Cattles do not have incisors in the upper jaw and hence are unable to crunch well, as a result lack the efficiency to graze the particles close. Both the cheek's inner side and the palate seem to be very rough. This roughness aids to hold the feed for some time and then masticate the feed in a SS (side-to-side) motion in reducing the particle size of the fed. Also, the saliva present in the mouth (produce approximately twenty to thirty-five gallons) of the cattle helps in the proper digestion of food by making the food moist. The saliva mainly composed of the chemicals like sodium bicarbonate and water, the former helps to maintain the rumen to retain the neutral $\mathrm{pH}$ which is between 6.5 to 7.2. This neutral $\mathrm{pH}$ helps to maintain a fair growth of microorganisms. The later present in the saliva is recycled to the body again by the cattle.

There are four compartments in the stomach of the cow namely rumen, reticulum, omasum, and abomasums respectively and each compartment differs for its functions (Figure 3).

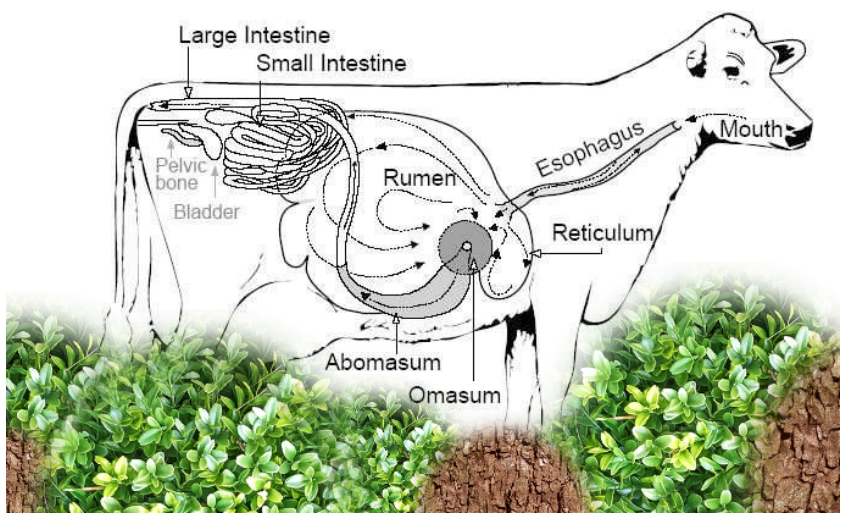

Figure 3. Compartments of the cattle stomach.

The four compartments present in the cow perform a particular process of digestion in order to break the hard and the larger food. Initially, cow eats the feed which is sufficient enough to swallow. The remaining unmasticated feed passes on to the first two compartments which is the rumen and reticulum where it is being stored and used later. The unmasticated or unchewed feed is known as "cud". The cow eats to the full quantity in the process of eating. While resting, the cow coughs-up the unmasticated feed known as "cud" and once again masticates the cud completely and swallows it again. This masticated feed gets completely digested when it enters into the third and fourth stomachs namely the omasum and abomasum. A small quantity of the digested food enters the blood circulation, from where it reaches the udder, a bag like 
structure. It is in the udder that the digested food gets converted into a product called milk. This milk product can be squeezed out from the teats present at the lower stomach at the back, when it is externally viewed. The remaining quantity of the digested food is used for its own nutrition (Figure 4$)^{12}$.

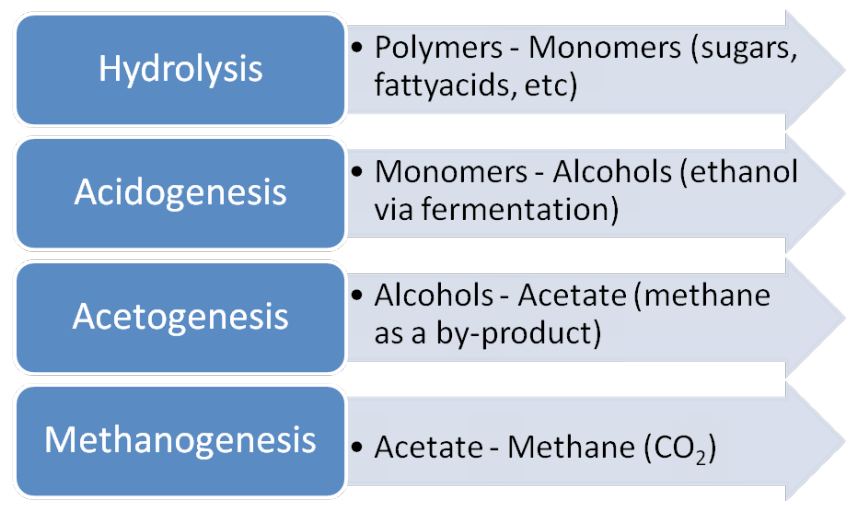

Figure 4. Mechanism of digestion process in Cow.

\section{Cow Dung}

Fundamentally, the dung of the cow is the throw-outs or discards containing the undigested herbivorous materials which are processed in their guts by the symbiotic bacteria which resides in the stomach compartment, rumen of the cow (Figure 5). These rejected matters or the faecal matter are very is rich in the mineral content (from the human point). The composition of the cow dung is mainly the organic matter which includes the fibrous material that has travelled through the digestive system of cow. There are also the left-overs of the liquid digestive substances which underwent the processes like fermentation, absorption, filtration and acidification. These are absorbed back again into the system. Further, the chemical composition contains largely carbon, nitrogen, hydrogen, oxygen, phosphorus, etc. with some of their salts. The cow dung also contains urea, mucus, as well as cellulose, lignin and hemicellulose.

While cow dung is just a waste by-product of the cattle, Ayurveda describes the cow dung (gomeya) as not mere a rejected material but as a best natural purifier (which purifies all the waste products of nature) ${ }^{13}$.

The cow dung contains approximately $80 \%$ of water which supports the undigested herbivorous medium containing beneficial microbial population and nutritive substances. Cow dung contains around twenty-four minerals like potassium, nitrogen, fewer quantities of sulphur, calcium, magnesium, manganese, cobalt etc. Also, it consists of crude fibres like cellulose with lignin, hemicelluloses and crude proteins. The overall composition of cow dung is the undigested fibre, sloughed off intestinal epithelium, fewer excreted products which are derived from mucus, bacteria present in the intestine and pigments of bile. The green colouration of the cow dung is due to the presence of the bile pigment called biliverdin. The emulgent property of the cow dung is also due to the salts of bile (confers hydrophilic coat to the hydrophobic droplets) ${ }^{14}$.

The microbial population of the cow dung consists of plentiful counts of bacilli (lactobacilli) and cocci. Few revealed and unknown and/or anonymous fungi and yeasts are also present. As a whole, more than sixty bacterial species, hundred species of protozoa and yeasts are present in the cow dung ${ }^{15-17}$. The composition of the cow dung is mentioned in Table 2.

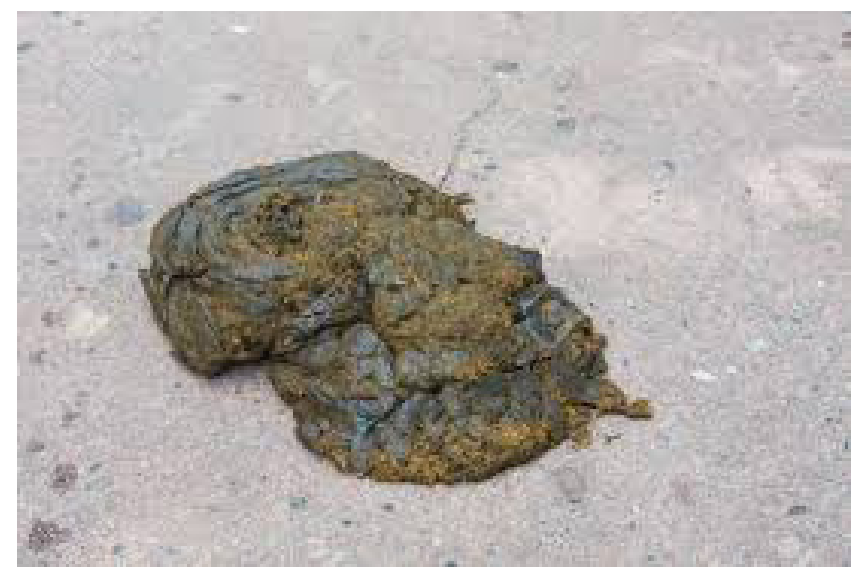

Figure 5. Fresh cow dung.

Table 2. Composition of cow dung

\begin{tabular}{|c|c|c|}
\hline S.No. & Composition & Percentage \\
\hline 1. & Water & $80 \%$ \\
\hline 2. & Nitrogen & $1.74 \%$ \\
\hline 3. & Phosphate & $1.7 \%$ \\
\hline 4. & Potash & $0.6 \%$ \\
\hline 5. & Calcium & $0.37 \%$ \\
\hline 6. & Magnesium & $0.53 \mathrm{ppm}$ \\
\hline 7. & Ferrous & $1400 \mathrm{ppm}$ \\
\hline 8. & Zinc & $90 \mathrm{ppm}$ \\
\hline 9. & Manganese & $210 \mathrm{ppm}$ \\
\hline 10. & Copper & $7.1 \mathrm{ppm}$ \\
\hline 11. & Boron & $5.0 \mathrm{ppm}$ \\
\hline 12. & Bacteria & 60 species \\
\hline 13. & Protozoans and & $100 \mathrm{species}$ \\
\hline
\end{tabular}


The cow dung obtained from a matured cow is approximately 5.4 tonnes per annum. This varies from the cow dung obtained from the calf. As a result, the dry cow dung would be nearly $1620 \mathrm{~kg}$ per annum (54. $\mathrm{x}$ $0.30)^{18}$. Hence, cow dung is considered as a "gold mine" because of the broad applications in department of resource of energy, department of agriculture, protection of environment department and the therapeutics ${ }^{19}$.

The various cows from the cross breed and indigenous were fed with the same food for around twenty-one days. The cow dung of all these cows were collected for six consecutive days. The collected cow dung was analysed on daily basis for the presence of the organic matters and the mineral composition. The comparative report of indigenous and cross breed cow is given in Table 3 .

Table 3. Comparison between gomeya (cow dung) of Indian indigenous cows and cross bred cows $^{20}$

\begin{tabular}{|c|c|}
\hline Contents & Findings \\
\hline Organic matter & Similar \\
\hline Nitrogen & Similar \\
\hline Manganese & Similar \\
\hline Calcium & $10 . \%$ higher in indigenous cow \\
\hline Phosphorous & $8 \%$ higher in indigenous cow \\
\hline Zinc & $84.1 \%$ higher in indigenous cow \\
\hline Copper & $21.7 \%$ higher in indigenous cow \\
\hline
\end{tabular}

\section{Cow Dung Cake Preparation}

The cakes or patties of cow dung are generally prepared by using various ratios of cow dung along with husk of paddy (dried state) and saw dust. The size and shape of the cake are optimized as per the user's choice. But usually, the size overall height and the diameter is one inch and six inches respectively ${ }^{21}$. The ratio of 76:24 percentage of cow dung and paddy husk yields the maximum calorie value of $15.44 \mathrm{MJ} / \mathrm{kg}$. Hence this optimized ratio is considered as the most stable mixture when compared with the other mixtures prepared ${ }^{22}$.

\section{Cow Dung Microbiome}

Cow dung has been considered as an infinite reserve mainly with respect to its diversified microbial population and there are not many sufficient studies ${ }^{23,24}$.

\subsection{Bacteria}

The ruminants consist of plentiful bacteria in the foregut with around 200 species and approximately $10^{10}$ to $10^{11}$ cells $/ \mathrm{ml}^{25}$. There are various factors which is responsible for various bacterial species present in the rumen namely choice of certain substrates in food, requirement of energy and confront some metabolic end-products which might be poisonous to certain species ${ }^{26}$. The bacteria which prevails more in the rumen are Prevotella, Butyrivibrio and Ruminococcus. The two majorly found enviable cellulose degraders are Fibrobacter succinogenes and Ruminococcus albus which also has the capability to digest the cellulose more powerfully that the cellulolytic bacteria ${ }^{27}$. The cows are also fed with the food containing high forage, from which an amylolytic bacteria, Streptococcus bovis is seen but very less in numbers ${ }^{28}$. Anaerobic bacteria are also found in bovine which obtain energy from the degradation of pectin. The popular pectinolytic species are Lachnospira multiparus, Prevotella ruminicola and Butyrivibrio fibrisolvens. These species are efficient in the conversion of pectin to oligogalacturonides by reduction process resulting in huge amounts of acetates. These acetates play a significant role in the metabolism process in bovine ${ }^{29}$. Presence of other anaerobic bacteria has also been confirmed. Rumen archaea - an anaerobic, is the single recognized microbe that exist in the rumen that produces methane and these archaea are called as methanogens which are seen in the rumen populated in the array of $1 \mathrm{ml}$ consisting $10^{6}$ to $10^{8}$ cells calculating for less than $4 \%$ of the total community of microorganisms ${ }^{30,31}$. Rumen fluid contains few varieties of protozoa ranging from 104 to $106 \mathrm{cell} / \mathrm{s} / \mathrm{ml}$ which are responsible for 30 to $40 \%$ of overall fibre digestion in bovine. There seems a dominating genus of protozoa named as Entodinium. This genus is present in the diet with high grains and performs a series of processes like swift degradation, engulfment and conversion of the starch into an iodophilic storage polymer. Also, these protozoa are comparatively very active in the hydrolysis of lipids and are responsible for the production of hydrogen through the hydrosomes present in them ${ }^{32}$. A study states that Campylobacter jejuni and Campylobacter fetus have huge impact on immunity, fertility and on the whole health of the $\operatorname{cow}^{33}$.

\subsection{Amoebae}

Amoebae also play a significant contribution to the pool of microbial environment. Unfortunately, the function of amoeba in rumen is imprecise. Amoeba might be imperative for the rumen and to the common health of bovine. 


\subsection{Fungi}

The fungi found in the rumen are anaerobic and found to be in the population of $10^{3}$ to $10^{6}$ zoospores/ $\mathrm{ml}$. These anaerobic fungi belong to the class Neocallimastigomycota. These contains six commonly known genera like Anaeromyces, Caecomyces, Cyllamyces, Neocallimastix, Orpinomyces and Piromyces with 21 identified species. In recent times, two genera Oontomyces and Buwchfawromyces was identified in cattle with the help of molecular techniques ${ }^{34,35}$.

\subsection{Bacteriophage}

The obligate pathogens of bacteria are called as bacteriophage. These bacteriophages are densely present in the digesta of the rumen with the approximate population of $10^{7}$ to $10^{9}$ particles per gram ${ }^{36}$.

\section{Qualities in Cow Dung}

Generally, if any organism consumes any toxic substances by any chance, the same will be distributed throughout the body and the excretory products (in any form) will have the portion of the consumed toxins. The above concept is not applicable in the life of cow. Though the cow consumes toxins accidentally, it is absorbed in the flesh. The shocking fact is that they do not let or release the toxins (in any form) in any of their direct and derived products like urine, dung or milk, even in minute amounts. Curiosity of this fact led the researchers to compare the same with the other mammals by adding various toxins and the respective animal's urine and milk were tested which confirmed small quantities of toxins. Henceforth, cow was confirmed to be the mammal whose urine and dung are pure, without toxins.

\section{"Yatvagasthigatampapamdehetishthtimamke} prasnatpanchgavyasyadahasagnirivendhnam"

It means "Whatsoever sins or any diseases present in my body starting from the skin to the entire bones, panchagavya (the five products) kills the diseases like the fire destroying the fuel while buring ${ }^{37}$.

The ancient scriptures affirm about the "suryaketu". It says that this suryaketu nerve is present in the hump of the shoulder which absorbs the dangerous radiations and it also cleanses the atmosphere. There is also a belief that this suryaketu nerve absorbs the medicinal properties from the atmosphere and these properties are transferred to the panchagavya. Hence, just the presence of cows immensely contributes to the environment ${ }^{38}$. Some of the evidences have revealed the continuous connectivity of cow dung between the natural and divine world along with the humans and the respective male and female elements in a consecutive cycle of life. This continous life cycle indiactes the movement of cow dung as a gift connecting the world of human-non-human-divine by providing propsperity to each other. It is believed that cow dung is considered as a miraculous reward of life cycle for an organism to die and reborn for the sake of growth of life once again. These are evidentually seen from the hindu rituals performed in the pooja called as "govardhan puja" 39 .

Practically, the cow dung is in its pure form when it is fresh. It is stated that the nature of the cow dung changes its form a bit after it falls on the ground or land. Usually, the cow dung if dried for around seven days and then mixed thoroughly under direct sunlight (during midday) so that the pathogenic bacteria and other microbes are killed. The resultant dry coarse powder obtained is blended with suitable substances or materials for the preparation of therapeutic formulations and other toiletry preparations ${ }^{40}$.

In Ayurveda, the majority of the medicinal preparations are to be formulated on gradually firing the cow dung patties. These cow dung patties play a significant role for the therapeutical property of the Ayurvedic medicines. Hence, if there are no cow dung patties, there are no medicinal properties for the formulation. It is also clear that many Ayurvedic medicinal preparations would not have existed without urine and dung of the cow. For many hundred years the fomentation was performed on infants, pregnant women and also during the postpartum of women using cow dung by the mid wifes of the Indian villages. These evidences of practices indicate more of such applications that the recent modern research community have not understood yet ${ }^{41}$. In mountain villages of Chitral District in north-western Pakistan, dried cow dung is used as talcum powder when babies are swaddled. ${ }^{29}$

The soils mineral content is increased when cow dung is added resulting in enhancing the resisting power of trees and plants attacked by the pests and other diseases. This stimulated the growth of the plant and also various essential actions namely the solubilization of phosphorous and the oxidation of sulphur ${ }^{42,43}$. The cow dung is dried completely and people who belong to the Northern parts of Nigeria name the resultant dried extract as "dalam" and/or "dalang". The people who live in North Cameroun use these dried cow dung extracts for treating infectious patients and also as an ingredient in the preparation of soup $^{44}$.

Scientific literatures have stated about the generation of useful bacteria by inserting old or musty dung of the cow into the throat of horse. The same method has also been mentioned in other places. These studies can also be extended for humans, since their physiology matches 
with mammals ${ }^{45}$. There is a technique in Ayurveda called "swedana". It is a technique used for the purification of ativisha. This purification method of ativisha uses the juice obtained from the cow as a basic substance known as gomeya rasa. The above-mentioned method transforms the old cow dung juice suitable for the human's consumption. This results in removing the impurities from the human body and also detoxifies the system ${ }^{46}$.

\section{Benefits of Cow Dung}

\subsection{Environmental Protection}

Cow dung is considered as an important substance in the preservation of the environment. The atmospheric temperature is balanced when the cow dung is burnt. Cow dung controls the radioactive rays and also the heat impact of the environment. The dwellers are protected by coating the walls and cleaning the floors of the house with the mixture of dung and water. The Bhopal gas leak in 1984 killed around 20,000 people, but the people who lived in the cow dung coated walls were less affected. Till today, cow dung is used to shield the radiation in the atomic power centres located in India and Russia. The ozone layer is strengthened when the cow dung is fired with ghee as a ritualistic practice. This also prevents the harmful radiations from sun and shields the earth. Overall, cow dung prevents the environmental pollution by keeping it away from pollutants and do not allow any harmful effects of radiation ${ }^{47}$. Reduction of acid content in water is processed to reduce the percentage of acid by the treatment of water with the dung. This procedure can be followed for cleansing the pond and also to neutralize the acid present in the pond.

\subsection{Antiseptic Property}

Cow dung possesses disease preventing properties. It destroys microorganisms which cause diseases, fermentation and putrefaction. Since olden days to till date (in some villages throughout India), there exists the habit of cleaning and moping the floors, especially the clay floorings using the mixture of water and cow dung. Slowly the above practice has vanished due to the transformation of the floorings from clay to mosaic, marble, granite, etc., but in some places still they follow this practice. People who still wanted to practice this traditional system, in spite of their flooring not made in clay, they sprinkle the mixture containing water at the entry of the door in their house. They believe that this traditional practice would prevent the entry of microorganisms into the living area. Dilute mixture of cow dung and water is used for washing the vessels used for the functions at home. In some places, the mixture of cow dung ash and water is used to wash or rinse the clothes before using it. This belief is practiced till date as a custom of Hindus believing that the cow dung ash mixture would kill the microbes, if present. These traditional practices confirm that our ancestors believed in the antiseptic action of the cow dung ${ }^{48,49}$. Then Mozhi et al. (2018) conducted experiment on different cow dung extractives. The extractives showed antimicrobial action by actingon pathogenic microbes present in human body including fungi. Specifically, the methanol extractive of the cow dung showed the best antimicrobial action compared to the other extractives by exerting its action on almost all the tested microbes ${ }^{50}$ (Table 4 ).

\subsection{Anti-fungal Property}

Cow dung contains anti-fungal compound. It inhibits the growth of Corophilous fungi and respective action also improved when mixed with the urine of cow. The antifungal action of the cow dung is due to patulodin-like compounds which is synthesized in large quantity by the bacteria Eupenicillium bovifimosum present in cow dung. Some of the studies have explained the inhibitory action of the dung of the cow towards many pathogenic fungi ${ }^{51}$. One study has stated about the inhibitory action of the cow dung aqueous extract ash on pathogenic bacteria ${ }^{52}$ (Table 4).

\subsection{Anti-viral Property}

There is a ritual named "Gobarlep" performed by Hindus. The meaning of "Gobarlep" is nothing but spreading of a thin film of the mixture of cow dung and water of the floors and walls. The films of the mixture of cow dung mainly consist of cellulose in an undigested form. The sizes of the particles are in macro size with a high $\mathrm{pH}$ to more than eight. When the moisture in the mixture gets evaporated due to natural sunlight drying, the alkaline content comes up forming a binding coat. The viral particles are mostly acidic in nature and hence when these particles fall on the ground containing a thin film of cow dung, they feel an ionic blow and eventually their virulent effect gets reduced. The neutral viral particles fall on the ground and get attached on to the film. Hence, there will not be any active microbes present on the ground when there is a coat of cow dung ${ }^{53}$.

\subsection{Anti-insect Property}

Smoldering the cow dung patties prevents entry of mosquitoes into houses. Coating the floor with fresh cow dung and water prevents the flies. The cow dung ashes 
control the entry of pests. Indian cultural practices have confirmed the same by their practice of firing the dung of cow during the dawn. They are also anti-pathogenic, however mostly anti-insecticide and de-odorant. The most traditional and popular ways of repelling mosquitoes is by using neem leaves with cow dung. Mandavgane et al.(2005) prepared mosquito repellents using cow dung, maida, guggulu and other ingredients and found to be effective ${ }^{54}$. Mukherjee et al (2020) reported that the burning of mosquito repellent prepared with cow dung reduces mosquito population without having any release of synthetic chemical gases ${ }^{55,56}$. Kranti et al.(2014) developed an environment friendly mosquito coil which contains the dung of cow, leaves of neem, leaves of tulsi, dust of saw, loban, maida powder and oil obtained from lemon grass ${ }^{57}$.

\subsection{As a Remedy for Skin Disorders}

Cow dung is a best skin tonic. Cow dung mixed with the crushed neem leaves and made as a paste. This paste is applied on boils and heat rashes for a fast remedy. A study by Mariam et al. (2017) documented the use of Bos taurus L. urine, dung and the bile in the regions of South Africa and Nigeria for treating skin infections ${ }^{58}$.

\subsection{Anti-oxidant Property}

Some unpublished data says that the cow dung smoke is a potential anti-oxidant. Jirankalgikar et al.(2016) reported the HPTLC profile of antioxidant action of cow dung with noticeable variations in inter-day and intra-day. The obtained profile would be much helpful for the evaluation of the cow dung quality and purity ${ }^{59}$. Panchagavya ghrit is a medicated ghee manufactured with the direct and derived products of cow like cow urine, cow dung, cow milk, curd of cow and cow ghee. It is reported for anti-oxidant property having free radical effective in degenerative diseases, cancer, liver diseases, etc. It also acts as a hepatoprotective $\mathrm{e}^{60-62}$.

\subsection{For Dental Disorders}

Cow dung polishes the tooth and prevents the toothache. Hence, cow dung can be one of the major ingredients in the preparation of toothpastes.

\subsection{In Eye Disorders}

The smoke which comes from the fired cow dung is allowed to be in contact with the eyes by closing and opening the eyelids frequently. This increases the tear secretion in eyes which cleanses the eyes and improves the vision, even for at old age. Patil et al.(2017) have prepared three formulations with cow dung and cow dung juice. They are used for night blindness, foreign body sensation in eye and good eye sight and diseases of sclera ${ }^{63}$.

\subsection{Sunscreen Agent}

Patil et al.(2019) has reported the sun protection activity of Indian cow dung as natural and organic sunscreen agent ${ }^{64}$.

\subsection{Anti-malarial Effect}

Smoke of incense sticks containing camphor and cow dung are used to prevent malaria. Fiden et al. (2006) compared the actions of cigarette smoke and cow dung to rabbit's and their lungs were histopathologically studied ${ }^{65}$.

Anti-tuberculin: The odour of cow dung kills the microbes related to tuberculosis. Hence, the tuberculosis patients are made to live for some time in the shed of cow. The odour of the cow dung is breathed by the tuberculosis patients. Cow urine is used to wash the patience cot many times.

\section{Controversial Insights of Cow Dung}

In a research, it has been stated about the highly dangerous risk of combined infections who live in close proximity to cows and/or their family member involved in cattle caring mainly $\operatorname{cows}^{79-80}$. A study has reported that cow dung is applied externally as an antiseptic on the stump of the cord immediately after the delivery and/or even some of the days after their delivery ${ }^{81}$. Though there are evidence and practices confirming the powerful antimicrobial effects of cow dung, the pregnancy deliveries performed in house involving the umbilical cord procedures and/ or discharged from the health centres after the cord procedures were counselled to take proper precautions. There is a risk of the incidence of new-born tetanus by the application of cow dung paste in the stump. Some of the raw practices in the name of rituals and beliefs were advised to be avoided since they are believed to have dangerous effects especially the rituals involving the application of plaster on the stump of the cord. Rather it can be replaced with the other medical practices or medicated plasters which are hygienic ${ }^{82}$. 
Table 2. Different applications of cow dung ${ }^{67-78}$

\begin{tabular}{|c|c|c|c|}
\hline S. No. & Product & Composition & Application \\
\hline 1. & Soap & $23 \%$ cow dung content and $7 \%$ cow urine. & Eczemas \\
\hline 2. & Toothpaste & $\begin{array}{l}10 \% \text { of cow dung and cow urine along } \\
\text { with } 2 \% \text { ghee }\end{array}$ & Cosmetic \\
\hline 3. & Skin tonic & Cow dung with crushed neem leaves & For boils and skin rashes. \\
\hline 4. & Antiseptic & Fresh cow dung & $\begin{array}{l}\text { Prophylactic (disease preventive) properties. } \\
\text { Washing the floor of houses and sprinkling of cow } \\
\text { dung solution is an Indian custom. }\end{array}$ \\
\hline 5. & Antifungal product & Cow dung and cow urine & Inhibits growth of Coprophilous fungi. \\
\hline 6. & $\begin{array}{l}\text { Anti-malarial } \\
\text { products }\end{array}$ & Fresh cow dung & Anti-malarial \\
\hline 7. & $\begin{array}{l}\text { Anti-tuberculosis } \\
\text { products }\end{array}$ & Cow dung and cow urine & $\begin{array}{l}\text { The mere odour kills the germs of tuberculosis. } \\
\text { The tuberculosis patients are placed in the shed of } \\
\text { the cow. Cow urine is used to wash the patience } \\
\text { cot many times. }\end{array}$ \\
\hline 8. & Panchagavya Ghruta & $\begin{array}{l}100 \mathrm{ml} \text { cow urine, } 100 \mathrm{ml} \text { of cow dung } \\
\text { (juice), } 100 \mathrm{ml} \text { cow milk, } 100 \mathrm{ml} \text { of curd } \\
\text { prepared from cow's milk, } 100 \mathrm{ml} \text { cow } \\
\text { ghee prepared from clarified butter }\end{array}$ & $\begin{array}{l}\text { Mental retardation, epilepsy, oedema, brain } \\
\text { weakness, pain in stomach, psychological } \\
\text { problems, anaemia, severe jaundice, memory loss, } \\
\text { piles. }\end{array}$ \\
\hline 9. & Dentifrice & $\begin{array}{l}\text { Cow dung ash } 1 \mathrm{~kg} \text {, coal powder, camphor } \\
\text { oil } 40 \mathrm{ml} \text {, sodium chloride solution } 320 \mathrm{ml}\end{array}$ & $\begin{array}{l}\text { Used in the treatment of the decay of teeth, tooth } \\
\text { sensitivity for cold and hot water, sore throat, } \\
\text { gums swelling, taste deterioration, tongue ulcers, } \\
\text { pyorrhoea, tonsillitis, for bad smell of mouth. }\end{array}$ \\
\hline 10. & $\begin{array}{l}\text { Gaumay Marham } \\
\text {-cow cream }\end{array}$ & $\begin{array}{c}500 \mathrm{~g} \text { cow dung cake powder, } 100 \mathrm{~g} \text { salts } \\
\text { of cow urine, } 400 \mathrm{~g} \text { - geru (red Ocher } \\
\text { powder), } 50 \mathrm{~g} \text { copper sulphate, } 1 \mathrm{~kg} \\
\text { petroleum jelly }\end{array}$ & $\begin{array}{l}\text { To treat the skin diseases, ringworm infection, } \\
\text { eczema, itching, infected wounds. }\end{array}$ \\
\hline 11. & $\begin{array}{l}\text { Nasal drug - Gopal } \\
\text { nasya }\end{array}$ & $\begin{array}{c}100 \mathrm{~g} \text { cow dung obtained from cow dung } \\
\text { of the new born cow dung (immediately } \\
\text { after birth), } 100 \mathrm{~g} \text { ankade milk (Sap of } \\
\text { Madar tree - Calotropis procera), } 150 \mathrm{~g} \\
\text { black pepper }\end{array}$ & $\begin{array}{l}\text { In the treatment of epilepsy, hysteria, loss of } \\
\text { consciousness, headache and sinus. (Gopal nasya } \\
\text { is filled in a tube. The epileptic patients can blow } \\
\text { this formulation in both the nose. They get cured } \\
\text { in two to three episodes of epilepsy. }\end{array}$ \\
\hline 12. & $\begin{array}{l}\text { Cow dung extract } \\
\text { spray }\end{array}$ & Cow dung extract & $\begin{array}{c}\text { Beneficial in the treatment of the bacterial blight } \\
\text { disease of rice. This extract is useful as efficient as } \\
\text { penicillin, streptomycin and paushamycin. }\end{array}$ \\
\hline 13. & $\begin{array}{l}\text { Cow dung mosquito } \\
\text { repellent }\end{array}$ & $\begin{array}{c}\text { Cow dung, lemon grass oil, vegetable } \\
\text { ghee, neem, peppermint oil, rice, saw } \\
\text { dust, raal (gum extracted from Sal tree } \\
\text { - Shaala), tulsi, vekhand (Calamus Root), } \\
\text { ajowan, maida }\end{array}$ & Effective against mosquitoes \\
\hline
\end{tabular}




\section{Cow Breed in Indian Postage Stamps}

The Department of Posts, Government of India commemorated the cow breed by releasing a postage stamp in its name (Figure 6).

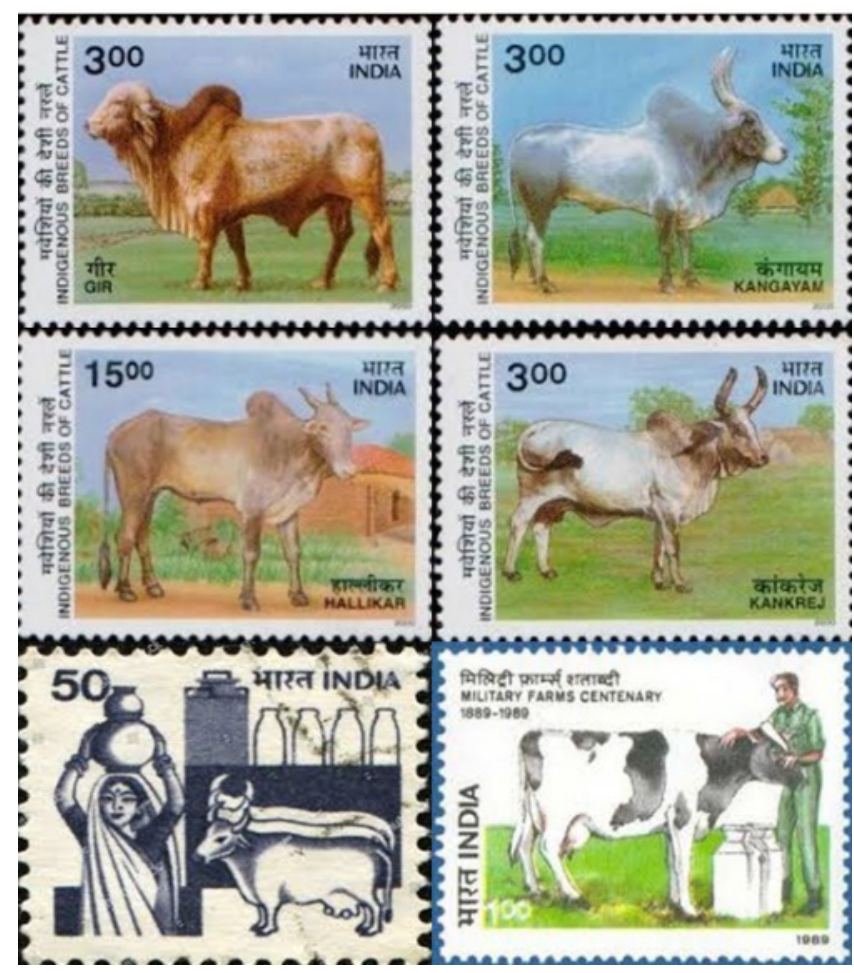

Figure 6. Postal stamps showing different cow breeds

These stamps play a significant role in society since they help in creating awareness about the indigenous animal breeds and bring attention on conservation of these valuable germ plasm, some of which are at the verge of extinction ${ }^{83}$.

\section{Research Initiatives by Indian Government on Cowpathy}

The Government of India has established "Scientific Utilisation Through Research Augmentation-Prime Products from Indigenous Cows" (SUTRA PIC). This establishment is supported by Science and Technology Ministry through DST (Department of Science and Technology), DBT (Department of Biotechnology), DSIR (Department of Scientific and Industrial Research), CSIR (Council of Scientific and Industrial Research), AYUSH (Ministry of Ayurveda, Yoga, and Naturopathy,
Unani, Siddha and Homoeopathy), MNRE (Ministry of New and Renewable Energy), ICAR(Indian Council of Agricultural Research) and ICMR (Indian Council of Medical Research).

\section{Conclusion and Future Perspectives}

Cow dung can also be used as one of the alternating resources of energy for a healthy nutritive living. The cow dung which is used in panchagavya therapy is a modern method adaptation of the olden science and certainly can be a potential preparation for the future. Hence, it is the need of the hour to create awareness and educate the human world regarding the applications and uses of cow dung. The vital medicinal properties of cow dung in panchagavya treatment requires further detailed studies for extracting more benefits. A standardized research investigation has to be performed on the natural composition by suitable and advances analytical techniques, microbial studies, and various studies on therapeutic activities. The biologically active compounds (NCE-New Chemical Entities) can be isolated for which the mechanism of action can be studied. These researches can also be extended to the clinical trials for prophylactic and also for the treatment of dreadful diseases in human. Researches have a broad scope of work to be done since every breed is unique, hence the products also would vary chemically and biologically. The changes may also be due to the feed provided to the cow. To conclude, the mutual combinatorial attempt of the educationalists, researchers and the doctors would definitely bring many miraculous economical therapeutical formulations. These formulations will surely not have any adverse effects and the patients would have faith in the scientific fraternity for their well-being.

\section{References}

1. Jonker JS, Kohn RA. Using milk urea nitrogen to evaluate diet formulation and environmental impact on dairy farms. Sci World J. 2001; 1:852-9. https://doi. org/10.1100/tsw.2001.265. PMid:12805886. PMCid:P MC6084535

2. Cattle. Available from: https://en.wikipedia.org/wiki/ Cattle

3. Available from: http://www.dahd.nic.in/documents/ reports

4. Available from:http://www.nbagr.res.in/cattle.html

5. Swamy S. The Cow Protection Bill, 2017, Bill No. VI of 2017. GMGIPMRND, 5505RS(S3). 2017 Mar. 
6. Available from: http://factsanddetails.com/world/ cat55/sub388/item 1347.html

7. Hockings P. Encyclopedia of the World Cultures: Volume 3 South Asia, edited by David Levinson, G.K. Hall \& Company, New York; 1994.

8. Kaushik R, Jain J, Rai P. Therapeutic potentials of cow derived products- A review. Int J Pharm Sci Res. 2016; 7(4):1383-90.

9. Rekhs S, Gupta L, Rakshapal, Omprakash R. Benefits of cow urine - A review. International Journal of Recent Advances in Multidisciplinary Research. 2017; 4(9):2833-55.

10. Shah CP, Patel DM, Dhami PD, Kakadia J, Bhavsar D, Vachhani UD et al. In vitro screening of antibacterial activity of cow urine against pathogenic human bacterial strains. Int J Curr Pharm Res. 2011; 3(2):91-2.

11. Dhama K, Chakraborty S, Tiwari R. Panchgavya therapy (Cowpathy) in safeguarding health of animals and humans - A review. Res Opin Anim Vet Sci. 2013; 3:70-178.

12. Hall JB, Silver S. Nutrition and feeding of the cowcalf herd: Digestive system of the cow. Virginia Cooperative Extension, Virginia Tech, VCE Publications; 2009.p. 1-4.

13. Lalitha KVS. A review on beneficial effects of cow dung. Int J Curr Res. 2019; 11(4):2771-3.

14. Nene YL. Seed health in ancient and medieval history and its relevance to present-day agriculture. Asian Agri-History. 1999; 3:157-84.

15. Sharma B, Singh M. Isolation and characterization of bacteria from cow dung of desi cow breed on different morpho-biochemical parameters in Dehradun, Uttarakhand, India. Int J Adv Pharm Biol Chem. 2015; 4:276-81.

16. Chin HC, Ahmad NW, Kian CW, Kurahashi H, Jeffrey J, Kiang HS, Omar B. A study of cow dung diptera in Sentul Timur, Kuala Lumpur, Malaysia. J Trop Med Parasitol. 2010; 33:53-61.

17. Macdonell AA, Keith AB. Vedic Index of Names and Subjects. 1st edition. Motilal Banarsidas, Varanasi; 2007.

18. Available from: https://trueayurveda.wordpress.com /2012/02/08/real-ghee-real-qualities-real-effects

19. Randhawa GK, Kullar JS. Bioremediation of pharmaceuticals, pesticides, and petrochemicals with Gomeya/cow dung. ISRN Pharmacol. 2011;
2011. https://doi.org/10.5402/2011/362459. PMid:22 084712. PMCid:PMC3197002

20. Garg AK, Mudgal V. Organic and mineral composition of Gomeya (cow dung) from Desi and crossbred cows-a comparative study. Int J Cow Sci. 2007; 3(1-2):17-19.

21. Nishteswar K, Vidyanath R. Ayurveda rasa shastra, Chapter 5. Chaukhamba Surbharati Prakashan, Varanasi; 2010. p. 38-42.

22. Pathiraja PMYS, Ranatunga YMMK, Herapathdeniya SKMK, Gunawardena SHP.Swarna Makshika Bhasma preparation using an alternative heating method to traditional Varaha Puta. J Ayurveda Integr Med. 2020; 11(3): 206-12. https://doi. org/10.1016/j.jaim.2018.02.136. PMid:30952470. PM Cid:PMC7527817

23. Hozzein WN, Ali DMI, Ali MIA. Genus diversity andantibacterial activities of some desert actinomycetes. J Union Arab Biologists. 2007; 17B:1530.

24. Hozzein WN, Rabie W, Ali MIA. Screening the Egyptian desert actinomycetes as candidates for new antimicrobial compounds and identification of a new desert Streptomyces strain. Afr. J. Biotechnol. 2011; 10:2295-301.

25. McSweeney CS, Mackie R. Micro-organisms and ruminant digestion: state of knowledge, trends and future prospects. Commission on Genetic Resources for Food and Agriculture. The Food and Agriculture Organization of the United Nations. 2012:1-62.

26. Castillo-Gonzalez AR, Burrola-Barraza ME, Dominguez-Viveros J, Chavez Martinez A. Rumen microorganisms and fermentation. Arch Med Vet. 2014; 46:349-61. https://doi.org/10.4067/S0301-732 X2014000300003

27. Koike S, Kobayashi Y. Fibrolytic rumen bacteria: their ecology and functions. Asian-Australasian J Anim Sci. 2009; 22(1):131-8. https://doi.org/10.5713/ ajas.2009.r.01

28. Fernando SC, Ii HTP, Najar FZ, Sukharnikov LO, Krehbiel CR, Nagaraja TG, Roe BA, Desilva U. Rumen microbial population dynamics during adaptation to a high-grain diet. Appl Environ Microbiol. 2010; 76(22):7482-90. https://doi.org/10.1128/AEM.0038810. PMid:20851965. PMCid:PMC2976194

29. Duskova D, Marounek M. Fermentation of pectin and glucose and activity of pectin-degrading enzymes in the rumen bacterium Lachnospira 
multiparus. Lett Appl Microbiol. 2001; 33:159-63. https://doi.org/10.1046/j.1472-765x.2001.00970.x. PMid:11472526

30. Hook SE, Wright AD, McBride BW. Methanogens: methane producers of the rumen and mitigation strategies. Archaea. 2010; 2010. https://doi.org/10.11 55/2010/945785. PMid:21253540. PMCid:PMC3021 854

31. Lin C, Raskin L, Stahl DA. Microbial community structure in gastrointestinal tracts of domestic animals: Comparative analyses using rRNA-targeted oligonucleotide probes. FEMS Microbiol Ecol. 1997; 22(28):281-94. https://doi.org/10.1111/j.15746941.1997.tb00380.x

32. Tymensen LD, Beauchemin KA, McAllister TA. Structures of free-living and protozoa-associated methanogen communities in the bovine rumen differ according to comparative analysis of $16 \mathrm{~S}$ rRNA and mcrA genes. Microbiology (Reading). 2012; 158(Pt 7):1808-17. https://doi.org/10.1099/mic.0.057984-0. PMid:22539164

33. Sahin O, Fitzgerald C, Stroika S, Zhao S, Sippy RJ, Kwan $\mathrm{P}$, et al. Molecular evidence for zoonotic transmission of an emergent, highly pathogenic Campylobacter jejuni clone in the United States J Clin Microbiol. 2012; 50(3):680-7. https://doi.org/10.1128/JCM.06167-11. PMid:22189122. PMCid:PMC3295108

34. Dagar SS, Kumar S, Griffith GW, Edwards JE, Callaghan TM, Singh R, et al. A new anaerobic fungus (Oontomycesanksri gen. nov., sp. nov.) from the digestive tract of the Indian camel (Camelus dromedarius). Fungal Biol. 2015 Aug; 119(8):731-7. https://doi.org/10.1016/j.funbio.2015.04.005. PMid: 26228561

35. Callaghan TM, Podmirseg SM, Hohlweck D, Edwards JE, Puniya AK, Dagar SS, Griffith GW. Buwchfawromyceseastonii gen. nov., sp. nov.: A new anaerobic fungus (Neocallimastigomycota) isolated from buffalo faeces. MycoKeys. 2015; 9(34):11-28. https://doi.org/10.3897/mycokeys.9.9032

36. Klieve AVA, Swain RAB, Nolan JVB. Bacteriophages in the Rumen; types present, population size and implications for the efficiency of feed utilisation. Popul (English Ed). 1996; 2(2):92-4.

37. Available from: https://www.speakingtree.in/blog/ natural-healing-of-cow-dung

38. Khan MY, Roy M, Saroj BK, Dubey S, Sharma VK. A Review - Benefits of Panchagavya therapy
(Cowpathy) for health of humans. Asian J Res Pharm Sci. 2015; 5(2):1-11. https://doi.org/10.5958/22315659.2015 .00019 .3

39. Notermans C. Prayers of cow dung: Women sculpturing fertile environments in rural Rajasthan (India). Religions. 2019; 10(2):71-96. https://doi. org/10.3390/rel10020071

40. Available from: https://www.telegraph.co.uk/expat/ expatnews/7398029/Cow-dung-and-urine-healthy. html

41. Available from: https://trueayurveda.wordpress.com /2012/02/08/real-ghee-real-qualities-real-effects

42. Dorothy S Mull, Jon Wanderson, Mull JD. Cow dung, rock salt, and medical innovation in the Hindu Kush of Pakistan: The cultural transformation of neonatal tetanus and iodine deficiency. Social Science and Medicine 1990; 30(6):675-91. https://doi. org/10.1016/0277-9536(88)90253-5

43. Sharma B, Singh M. Isolation and characterization of bacteria from cow dung of desi cow breed on different morpho-biochemical parameters in Dehradun, Uttarakhand, India. Int J Adv Pharm Biol Chem. 2015; 4:276-81.

44. Rajeswari S, Poongothai E, Hemalatha N. Antimicrobial activities of cow dung extracts against human pathogens. Int J Curr Pharm Res. 2016; 8(4):912. https://doi.org/10.22159/ijcpr.2016v8i4.15268

45. Lans C, Turner N, Brauer G, Lourenco G, Georges K. Ethnoveterinary medicines used for horses in Trinidad and in British Columbia, Canada. J Ethnobiol Ethnomed. 2006; 2:31. https://doi.org/10.1186/17464269-2-31. PMid:16893454. PMCid:PMC1559680

46. Rasve VR, Paithankar VV, Shirsat MK, Dhobale AV. Evaluation of Antiulcer activity of Aconitum heterophyllum on experimental animal. World J Pharm Pharm Sci.2018; 7(2):819239.

47. Somvanshi R. Veterinary medicine and animal keeping in ancient India. Asian Agri-History. 2006; 10(2):133-46.

48. Chauhan RS, Singh BP, Singhal LK. Immunomo dulation with Kamdhenu Ark in mice. J Immunol Immunopathol. 2001; 71:89-92.

49. Jain NK, Gupta VB, Garg R, Silawat N. Efficacy of cow urine therapy on various cancer patients in Mandsaur District, India - A survey. Int. J. Green Pharm. 2010; 4(1): 29-35. https://doi.org/10.4103/0973-8258.62163

50. Thenmozhi S, Mageswari M, Chinnamani S, Sivasuriyan S. Antimicrobial activity of animal waste 
(Jersey Cow dung). World Journal of Science and Research 2018; 3(1): 37-41.

51. Basak AB, Lee MW, Lee TS. Inhibitive activity of cow urine and cow dung against sclerotinia sclerotiorum of cucumber. Mycobiology. 2002; 30:175-9. https:// doi.org/10.4489/MYCO.2002.30.3.175

52. Waziri M, Suleiman JS. Analysis of some elements and antimicrobial activity of evaporated extract of cow dung against some pathogens. J Sci Res. 2013; 5:135-411. https://doi.org/10.3329/jsr.v5i1.11962

53. Bhattacharya D, Bibalani GH, Samadiyan V, Pouyanfar M, Mohanta PK, Pradhan PK, Mohamadpour P. COVID - 2019 and Indian Medicine Sources: Drug Discovery Attempt. Indian Journal of Natural Sciences. 2020; 10(61):27541-52.

54. Mandavgane SA, Pattalwar VV, Kalambe AR. Development of cow dung based mosquito repellent. Nat Prod Radiance. 2005; 4(4):270-73.

55. Mukherjee G, Ghosh S. Use of cow dung as mosquito repellent. International Research Journal of Pharmacy and Medical Sciences 2020; 3(1):61-2.

56. Palanisami S, Natarajan E, Rajamma R. Development of eco-friendly herbal mosquito repellent. J Innovative Biol. 2014; 1(3):132-6.

57. Sharma K, Mishra S, Dubey A. Development of cow dung based herbal mosquito repellent. Journal of Krishi Vigyan. 2017; 6(1):50-3. https://doi. org/10.5958/2349-4433.2017.00048.4

58. Oyedeji-Amusa MO, Oladele OT, Ashafa AO. Ethnoveterinary survey of tradomedical importance of Bos taurus L urine, bile and dung in Nigeria and South Africa. Trop J Pharm Res. 2016; 15(8):1807-13. https://doi.org/10.4314/tjpr.v15i8.30

59. Jirankalgikar N, Nariya $P$, De S. In vitro antioxidant activity evaluation and HPTLC profile of Cow dung. Int J Green Pharm. 2014; 8:158-62. https://doi. org/10.4103/0973-8258.140172

60. Jirankalgikar NM, Nariya PB, Athavale AV, De S. Trividha Snehapaka of Panchagavya Ghrita: A critical comparative evaluation. J Ayurveda Integr Med. 2013; 4(2):107-13. https://doi.org/10.4103/09759476.113887. PMid:23930043. PMCid:PMC3737442

61. Pandey A, Pawar MS. Assessment of nootropic activity of Panchagavya Ghrita in animal models. Int J Sci Res.2015; 5(8):1-5.

62. BhojrajN, Sawarkar G. The effect of Panchagavya formulations in the case of CA Rectum. Int J Ayurvedic
Med.2020; 11(3):572-4. https://doi.org/10.47552/ija m.v11i3.1625

63. Patil S, Joshi M. Study of formulations of Shalakya Tantra from Yogashatakam. World J Pharm Pharm Sci. 2017; 6(4):1334-41. https://doi.org/10.20959/ wjpps20174-8900

64. Patil PA, Kolekar M, Koli V, Kamble A. Evaluation of Sun Protective Formula (SPF) of Indian cow dung as organic sunscreen agent. Research Journal of Topical and Cosmetic Sciences. 2019; 10(1):7-8. https://doi. org/10.5958/2321-5844.2019.00002.5

65. Fidan F, Unlu M, Sezer M, Sahin O, Tokyol C, Esme $\mathrm{H}$. Acute effects of environmental tobacco smoke and dried dung smoke on lung histopathology in rabbits. Pathology. 2006; 38(1):53-7. https://doi. org/10.1080/00313020500459615. PMid:16571591

66. Mfinanga SG, Morkve O, Kazwala RR, Cleaveland S, Sharp JM, Shirima G, et al. The role of livestock keeping in tuberculosis trends in Arusha, Tanzania. Int J Tuberc Lung Dis. 2003; 7:695-704.

67. Dhama K, Rathore R, Chauhan RS, Tomar S. Panchgavyaan overview. Int J Cow Sci. 2005; 1(1):115.

68. Das A, Satyaprakash K. Antimicrobial properties of natural products: A review. The Pharma Innovation Journal. 2018; 7(6):532-7.

69. Available from: https://qz.com/india/1023727/whatbetter-way-to-show-your-devotion-to-the-cowthan-by-brushing-your-teeth-with-dung

70. Dhama K, Rathore R, Chauhan RS, Tomar S: Panchgavya- An overview. Int J Cow Sci. 2005; 1(1):115.

71. Schnürer J, Magnusson J: Antifungal lactic acid bacteria as biopreservatives - Review. Trends Food Sci Technol. 2005; 16(1-3):70-8. https://doi. org/10.1016/j.tifs.2004.02.014

72. Kulkarni SK: Hand book of experimental pharmacology. 3rd edition. Vallabh Prakashan, New Delhi; 2009.

73. Available from: https://sanskritdocuments.org/sites/ gomAtA/Cow-Ayurvedic-Panaceas.pdf

74. Wal A, Wal P, Saraswat N, Sharma CP, Rai AK. Therapeutic effects of cow urine and cow dung. European J Biomed Pharm.2016; 3(5):192-200.

75. Dorothy ET, Frisvad, JC. Eupenicillium bovifimosum, a new species from dry cow manure in Wyoming. 
Mycologia. 2002; 94(2):240-6. https://doi.org/10.108 0/15572536.2003.11833229

76. Lehr NA, Meffert A, Antelo L, Sterner O, Anke $\mathrm{H}$, Weber RW. Antiamoebins, myrocin $\mathrm{B}$ and the basis of antifungal antibiosis in the coprophilous fungus Stilbella erythrocephala (syn. S. fimetaria). FEMS Microbiol Ecol. 2006 Jan; 55(1):105-12. https://doi.org/10.1111/j.1574-6941.2005.00007.x. PMid:16420619

77. Mandavgane SA, Pattalwar AA, Kalambe AR. Development of Cow dung based herbal based mosquito repellent. Nat. Prod. Radiance. 2005; 4(4):270-3.

78. Khan MY, Roy M, Sarkar BKR, Kattula D, Francis MR, Ajjampur SS, et al. Risk factors for cryptosporidiosis among children in a semi urban slum in southern India: A nested case-control study. Am J Trop Med Hyg. 2014; 91(6):1128-37. https://doi. org/10.4269/ajtmh.14-0304. PMid:25331810. PMC id:PMC4257634
79. Murugesan M, Ganesan SK, Ajjampur SSR. Cryptosporidiosis in children in the Indian subcontinent. Trop Parasitol. 2017; 7(1):18-28.

80. Yaqub KM, Roy M, Kumar SB, Sudhakar D, Kumar SV. A Review- Benefits of Panchgavya therapy (Cowpathy) for health of humans. Asian J Res Pharm Sci. 2015; 5(2):115-25. https://doi.org/10.5958/22315659.2015 .00019 .3

81. Bennett J, Macia J, Traverso H, et al. Protective effects of topical antimicrobials against neonatal tetanus. Int J Epidemiol. 1997; 26(4):897-903. https://doi. org/10.1093/ije/26.4.897. PMid:9279625

82. World Health Organization. Care of the Umbilical Cord, A review of the evidence. Geneva, WHO/RHT/ MSM/98.4; 1998.p. 9-18.

83. Somvanshi R. Our Pride: Indigenous livestock breeds depicted on Indian postage stamps. RASSA Journal of Science for Society. 2019; 1(1-2):27-31. 